\title{
Foot-and-mouth disease: overview of motives of disease spread and efficacy of available vaccines
}

\author{
Ali Saeed ${ }^{1 \dagger}$, Sehrish Kanwal ${ }^{1}$, Memoona Arshad ${ }^{2}$, Muhammad Ali ${ }^{1}$, Rehan Sadiq Shaikh ${ }^{1}$ and \\ Muhammad Abubakar ${ }^{3 *}$
}

\begin{abstract}
Control and prevention of foot and mouth disease (FMD) by vaccination remains unsatisfactory in endemic countries. Indeed, consistent and new FMD epidemics in previously disease-free countries have precipitated the need for a worldwide control strategy. Outbreaks in vaccinated animals require that a new and safe vaccine be developed against foot and mouth virus (FMDV). FMDV can be eradicated worldwide based on previous scientific information about its spread using existing and modern control strategies.
\end{abstract}

Keywords: Attenuated virus, Foot-and-mouth disease, In-activated virus, Recombinant virus, Transgenic vaccines

\section{Introduction}

Foot-and-mouth disease (FMD) is one of the most economically and socially devastating diseases affecting cloven-hoofed livestock worldwide. It is caused by a highly variable RNA virus with seven serotypes (A, O, C, Asia 1, SAT 1, SAT 2, and SAT 3) and a large number of topotypes [1]. Millions of animals are sacrificed every year worldwide under FMDV eradication programmes [2]. FMDV has continuously circulated ever since after the first outbreak in America in 1870 [3,4]. Further, new subtypes of FMDV are continuously evolving due to an infinite mutation rate in the RNA genome of the virus [5].

Over the last few decades, disease-free countries have primarily adopted the strategy of slaughtering carrier animals combined with transport restrictions and other sanitary measures. Additionally, rapid vaccination is applied to limit the spread of infection in outbreak regions [6,7].

Currently, inactivated vaccines are used as a major tool in FMD eradication programmes in Europe as well as other parts of the world. However, these vaccines have a number of limitations such as propagation of virulent virus, threat of virus escape from manufacturing sites, limited shelf-life, and booster injection requirement after 4-12 months [8]. Sterility, safety, cost-effectiveness, easy delivery, and long-lasting immunity against multiple

\footnotetext{
* Correspondence: mabnvl@gmail.com

${ }^{\dagger}$ Equal contributors

${ }^{3}$ National Veterinary Laboratory, Park Road, Islamabad, Pakistan

Full list of author information is available at the end of the article
}

serotypes are additional challenges associated with conventional inactivated vaccines [8].

Recently, transgenic vaccines were demonstrated as a novel and safe strategy for the control and prevention of FMD. Specifically, animal fodder-based edible transgenic vaccines containing protein-expressing viral genomes are feasible to immunize animals. Many studies have suggested that FMD plant-derived edible vaccines will become common within the next few years [9].

\section{Review \\ Continent disease spread}

Control of FMD is difficult due to variations in viral serotype and consistency, effectiveness of control measures, and emergence of new subtypes. FMD outbreaks also originate from transportation of carrier animals to susceptible populations or disease-free regions. Moreover, prevalence of FMD increases due to seasonal or periodic cycling, host susceptibility, and predisposal to epizootic risk [10]. There are still many gaps in our understanding of FMD, especially in Asian countries. Rapid investigation of outbreaks samples and interpretation of data are made possible due to recent development of tools and techniques. Independent and collaborative works by various national animal health services, key control initiatives, laboratory networks, and many other groups have improved our knowledge of FMD [10].

Many countries have obtained FMD-free status from the International Organization of Animal Health (OIE) 
with or without vaccination. However, FMD has reemerged in previously disease-free countries due to increased viral escape from vaccinated animals and import of animal products from FMDV-circulating countries. Many countries have maintained their disease-free status by strict monitoring and culling of infected animals $[11,12]$. The southern part of South America achieved FMD-free status from the OIE in the late 1990s with the help of a strict eradication program, and other countries such as Uruguay, Argentina, Paraguay, and Brazil achieved FMD-free status via vaccination in 1994, 1997, 1997, and 1998, respectively [13].

Recently, FMD has reemerged in Japan and South Korea. Japan first achieved FMD-free status without vaccination in 2000, and FMD O serotype has not been reported in Mongolia and Russia since 2003 and 2004, respectively. In 2010, FMD serotype A and O outbreaks were reported in South Korea and Japan, respectively. However, FMD A outbreak in South Korea was controlled by March 2010 while the FMD O outbreak in Japan was controlled by June 2010 [12]. FMD outbreaks of serotype $\mathrm{O}$ continue to pose a threat to livestock industries in this region (Table 1) [14].

\begin{tabular}{lll}
\multicolumn{2}{l}{$\begin{array}{l}\text { Table } \mathbf{1} \text { Countries with FMD free status in } \\
\text { to OlE [12] }\end{array}$} & \multicolumn{1}{l}{ according } \\
\hline Albania & Germany & New Caledonia \\
Australia & Greece & New Zealand \\
Austria & Guatemala & Nicaragua \\
Belarus & Guyana & Norway \\
Belgium & Haiti & Panama \\
Belize & Honduras & Poland \\
Bosnia and Herzegovina & Hungary & Portugal \\
Brunei & Iceland & Romania \\
Canada & Indonesia & San Marino \\
Chile & Ireland & Serbia \\
Costa Rica & Italy & Singapore \\
Croatia & Japan & Slovakia \\
Cuba & Latvia & Slovenia \\
Cyprus & Lesotho & Spain \\
Czech Rep. & Lithuania & Swaziland \\
Denmark & Luxembourg & Sweden \\
Dominican Republic & Madagascar & Switzerland \\
El Salvador & Malta & Ukraine \\
Estonia & Mauritius & United Kingdom \\
Finland & Mexico & United States \\
& of America \\
Former Yug. Rep. & Montenegro & Vanuatu \\
of Macedonia & & \\
France & Netherlands & \\
\hline & & \\
\hline & &
\end{tabular}

Major causes of FMD spread in Asian/developing countries Asian countries suffering from FMD outbreaks often lack coordinated or serious mandatory measures for control of this disease. Further, movement and exchange of animals and animal products across neighboring countries are very common. The amount of FMD vaccines produced locally is insufficient to fulfill the demands of large populations of animals in developing countries $[5,15,16]$. Moreover, FMD outbreaks among vaccinated animals in this region may be due to poor vaccine quality, lack of knowledge of circulating subtypes, and suboptimal vaccination strategies such as single vaccine injection without any booster [15].

\section{Virus distribution}

Serotypes O, A, and Asia 1 are continuously circulating in many FMD endemic countries in Asia, Europe, and as well as Africa. Moreover, serotype $\mathrm{C}$ was reported in the Philippines in 1995, whereas SAT 1, 2, and 3 are common in African countries. Recently, disease-reporting transparency has improved due to increased field surveillance, outbreak investigation, and submission of virus samples for analysis by central reference laboratories such as the World Reference Laboratory (WRL) and FAO/OIE Reference Laboratory. However, efforts are still insufficient for comprehensive control and complete disease eradication $[10,17]$.

\section{Serotype 0}

FMDV serotype $\mathrm{O}$ is the predominant serotype of FMD worldwide. It is the most prevalent serotype in many parts of Africa, the Middle East such as Pakistan, and some parts of Europe. However, an accurate genetic explanation for the higher prevalence of $\mathrm{O}$ serotype is not yet available $[18,19]$. Serotype $O$ has been responsible for severe disease outbreaks in Taiwan, Korea, Pakistan, Iran, Afghanistan, Israel, China, North Korea, and Bulgaria $[17,20,21]$. O1Manisa vaccine has been proven to be a robust immune dominant strain in many FMD O outbreaks, but it still does not protect against all epidemics. Moreover, several other $\mathrm{O}$ serotype vaccines have been used to improve vaccine efficacy for circulating outbreaks [10].

\section{Serotype A}

Members of this serotype show high antigenic diversity and no cross-protection between strains [16,22-24]. Genetic recombination is more common in serotype A than in other serotypes of FMD $[25,26]$. Serotype A is prevalent in ruminant populations of Thailand and Malaysia. The most recent outbreaks of serotype A were reported in Pakistan, Turkey, Egypt, India, China, and South Korea. Serotype A has been successfully controlled and eradicated in South Korea [17]. Different vaccines for serotypes A confer variable levels of protection. A Iran-05, A22 Iraq, and A24Cruzeiro serotypes 
were found to be very useful as vaccines against serotype A $[10,17]$.

\section{Serotype Asia 1}

Serotype Asia 1 is the most antigenically stable serotype and shows relatively low levels of antigenic variation, although it is still capable of antigenic drift. Various historical epizootics have been reported mainly in Southeast Asian countries. Recently, serotype Asia 1 was shown to affect ruminants in China, Pakistan, Bahrain, Iran, Turkey, and Afghanistan in a cyclical pattern [17]. The Asia 1/ Shamir immune dominant serotype has been proven to be a very valuable serotype to control outbreaks in Asian countries and is still recommended to address FMD Asia 1 outbreaks [17].

\section{Serotypes SAT 1, 2, 3}

SAT (Southern African Territories) serotypes are usually found in Africa, but a few outbreaks were recorded in Saudi Arabia and Kuwait in 2000 [27]. SAT have genetically more diverse FMD serotypes than other regions [28]. SAT 1 was reported in 2003, 2006, and 2009 in South Africa, whereas SAT 2 as reported in South Africa, Botswana, and Tanzania in 2008, 2010, and 2012 respectively. SAT 3 was last reported in 2006 in South Africa [17].

\section{Serotype C}

Sporadic outbreaks of serotype $C$ have been reported in South America, East Africa, and Pakistan between 2000 and 2006 [29]. There have been no major epidemics in the last 20 years of this serotype [29]. Use of serotype C in vaccination may actually increase the risk of vaccineinduced outbreaks [30].

\section{FMDV genome and its role in infection}

FMDV is an infectious RNA virus divided into three major functional regions. It comprises a $5^{\prime}$ non-coding regulatory region, protein-coding ( $\mathrm{L} / \mathrm{P} 1, \mathrm{P} 2$, and $\mathrm{P} 3)$ region, and 3' non-coding regulatory region. The protein P1 coding region encodes four structural capsid proteins, whereas P2-P3 regions encode non-structural proteins for replication and viral maturation. The functions of the nonstructural proteins are still poorly understood [6,31].

\section{Initiation of infection}

FMDV infection is initiated by attachment of the RGD loop of viral capsid protein (VP1) to host surface integrins on target cells. This interaction between virion and cells is altered in some cell cultures in which a selected stretch of VP3 binds to heparin-like moieties on the cell culture surface [32]. AVB3 (Alpha V Beta), AVB5, and AVB6 integrins are virus attachment receptors in cattle [33].

\section{Virus immune response and vaccines}

Insufficient FMDV immunity can be attributed to the epitope between amino acids 140 to 160 having affinity for only B lymphocytes and not $\mathrm{T}$ lymphocytes. Identification of $\mathrm{T}$ lymphocyte-stimulating epitopes is thus a requirement for future vaccines. The three dimensional structure of FMDV includes a G-H loop in VP1 [4]. This G-H loop (highly conserved arginine-glycine-aspartic acid sequence) participates in binding to cell receptors $[6,34,35]$. Moreover, viruses containing a single point mutation in the RGD segment of VP1 regain virulence upon restoration of the RGD sequence [36]. However, RGD-deleted vaccines perform similar/better than BEIinactivated ones with respect to protection against challenge and induction of immune response. Thus, an effective vaccine can be prepared by deletion of cellbinding sites from the virus using a genetic engineering approach [37].

\section{Current major vaccines}

Vaccination is a major approach for controlling the spread of FMD. Inadequate safety and disease protection associated with conventional (inactivated or attenuated) vaccines has precipitated the need to develop effective and safe FMD vaccines. Adequate epidemiological data and revaccination times for different circulating serotypes are important for control of FMD in endemic regions [38]. Production of FMD vaccine requires large-scale antigen propagation, viral treatment for loss of pathogenicity, and adjuvant addition to enhance the immune response [39]. Good quality vaccines will allow avoidance of production loss and incidence of FMD [40]. Oil adjuvant of the Montanide series appears to be a promising candidate for a new generation of FMD vaccines [41]. Previously developed FMD vaccines were mostly ineffective [8] (Tables 2 and 3 ).

\section{Inactivated and attenuated vaccines}

Inactivated vaccines are commonly used and effective tools to address FMDV outbreaks, but their production is expensive and is associated with risk of disease spread [38]. Virus propagated on cell culture (BHK-21) and chemically inactivated by binary ethyleneimine has been shown to be an effective vaccination protocol. Vaccine inactivated by aziridine and acetylethyleneimine and mixed with adjuvant such as aluminum hydroxide or saponin has been used at large scale due to its reliability

Table 2 FMD free areas without vaccination [12]

\begin{tabular}{ll}
\hline Argentina & Moldova \\
Botswana & Namibia \\
Brazil & Peru \\
Colombia & Philippines \\
Malaysia & \\
\hline
\end{tabular}


Table 3 Priority of different serotype of foot and mouth disease for vaccination

\begin{tabular}{lll}
\hline $\begin{array}{l}\text { High priority } \\
\text { serotypes }\end{array}$ & $\begin{array}{l}\text { Medium priority } \\
\text { serotypes }\end{array}$ & $\begin{array}{l}\text { Low priority } \\
\text { serotypes }\end{array}$ \\
\hline O Manisa & A Eritrea & $\begin{array}{l}\text { A15 Bangkok } \\
\text { related strain }\end{array}$ \\
O BFS or Campos & A Iran '96 & $\begin{array}{l}\text { A87 Argentina } \\
\text { related strain }\end{array}$ \\
A24 Cruzeiro & SAT 2 Zimbabwe & C Noville \\
Asia 1 Shamir & A Iran 87 or A Saudi & SAT 2 Kenya \\
A Iran-05 & Arabia 23/86 & \\
A22 Iraq & A Malaysia 97 & SAT 1 Kenya \\
SAT 2 & A Argentina 2001 & SAT 3 Zimbabwe \\
- & O Taiwan 97 & A Kenya \\
\hline
\end{tabular}

and effectiveness [34]. In the early 1990s, studies revealed that vaccinated animals lack an immune response to non-structural proteins (NSPs) from viruses. This information can be used for serological screening of infected and carrier animals during vaccination. The manufacturers always face the problem of incomplete inactivation of virus along with screening of vaccinated and non-vaccinated animals [36,42].

Moreover, vaccine production against individual FMD serotypes is very challenging using a virus inactivation approach. Such vaccines may also lose potency and effectiveness from production to application due to errors in the cold delivery chain and field-limiting serotypes or topotypes. Further, short-lived immunity requires a booster, and inability to eradicate virus from carrier animals presents some limitations related to inactivated vaccines $[34,43]$.

Recently, inactivated FMDV (iFMDV) vaccines (CliptoxTM) have been shown to produce a specific antibody response in mucosal tissues and sera along with a Th1/Th2 response [44]. Previously, FMDV receptor or receptorbinding site-deleted/replaced FMDV attenuated vaccine has been explored for FMD protection in cattle $[44,45]$. Live attenuated vaccines prepared from leader proteinasedeficient serotype A12 and capsid containing $3 \mathrm{C}$ proteinase coding regions of Asia I/HNK/CHA/05 provide effective protection to cattle from FMDV. These studies validate the successful use of live/attenuated vaccine for FMD protection in endemic areas [46-48].

\section{Peptide vaccine}

Synthetic peptides are another promising technology for the control of FMD. A single epitope such as the G-H loop in the viral capsid and C-terminal region of VP1 correspond to B cell epitopes and stimulate an immune response with limited disease protection [49,50]. In addition, B cell affinity sites on VP1 as well as TH sites outside of VP1 are needed for production of neutralizing antibodies with high affinity. A peptide vaccine with both immunogenicity and antigenic cross-reactivity among serotypes was successfully developed from the entire G-H loop domain, flanking sequences (129-169), and artificial TH site of FMDV serotype $\mathrm{O}$ [31,51]. Immunization with peptides containing G-H loop either alone or in combination with an independent $\mathrm{T}$ cell epitope has been shown to induce $23 \%$ to $39 \%$ partial protection from viral infection $[31,36]$.

Partial or complete removal of the VP1 G-H loop is a novel approach to develop FMDV negatively marked vaccines [52]. Dendrimeric peptide vaccine specifically induces high titers of FMDV-neutralizing antibodies and activates an FMDV-specific $\mathrm{T}$ cell response in pigs. Animals immunized with peptide vaccine are protected against specific FMDV challenge [53]. Peptide vaccines have limitations such as incomplete protection due to a limited number of antigenic sites that interact with the immune system, discontinuous antigenic sites on VP1, and the quasi species nature of the virus [51]. These limitations of peptide vaccines allow for different FMDV antigenic variants, resulting in outbreaks in vaccinated animals. Future peptide vaccines should have advanced and paramount viral structures to induce effective and complete immune responses [54].

\section{Recombinant protein of FMD}

Recombinant proteins are an alternative immunization method and are based on a set of effective epitopes within a single polypeptide chain. $\mathrm{B}$ and $\mathrm{T}$ cell polyepitope proteins can also be used to induce an effective immune response [55]. In previous studies, FMD synthetic polypeptides were shown to protect laboratory animals such as mice, rabbits, and guinea pigs. However, there is still no recombinant FMD vaccine commercially available for farm animals [56,57]. It has previously been shown that empty FMDV capsids are capable of eliciting the same antibody response as infectious FMDV particles [58]. Recombinant vaccine from B cell epitopes of VP1 and VP4 as well as T cell epitopes of proteins $2 \mathrm{C}$ and $3 \mathrm{D}$ was previously developed in E.coli or $N$. benthamiana plants using a phytoviral expression system. Immunization of guinea pigs with purified proteins has been shown to induce an efficient immune response against FMDV serotype O/Taiwan/99 as well as protection against homologous viral challenge [59]. Therefore, recombinant polyepitope viral proteins may be used as commercially available vaccination tools for the control and prevention of FMD in the future.

\section{FMDV live vector vaccine}

A promising novel FMD vaccination approach was developed using replication-defective human adenovirus serotype 
5 (Ad5) containing FMDV transgenes [60]. Adenovirusvectored vaccines with interferon or FMDV capsid proteins co-expressed with viral protease for processing have been shown to confer protection against FMD in pigs and cattle [61]. Previously, an experimental vaccine was also developed using replication-defective human adenovirus serotype 5 (Ad5) containing transgenes from FMDV P1 (coding for capsid proteins), NSP 2A, 2B, nearly all $3 \mathrm{~B}$, and $3 \mathrm{C}$ protease [62]. In another study, Ad5-A24-modified candidate also successfully protected animals against challenge with homologous FMDV. Similarly, FMD construct without 3D (polymerase) NSP portion was used to successfully differentiate among FMDV infected and vaccinated animals [63].

Pseudorabies virus-derived virus-like particles (VLPs) are highly immunogenic and helpful for safe production of FMD proteins in vaccinated animals [48]. Previously, single vaccination with an empty capsid from FMDV serotype Asia I/HNK/CHA/05 expressed by a silkworm baculovirus expression vector protected $80 \%$ of cattle from virulent homologous virus [64]. In the future, adenovirus or other viral-associated recombinant vaccines may be successful commercial candidates for the control and prevention of FMD.

\section{Transgenic vaccine in plants}

Transgenic vaccines in plants were first discussed by Mason [65]. Such vaccines are now considered as a promising option for linear epitopes. Further, FMDV edible vaccines in transgenic plants as bioreactors may overcome problems with cold storage and transportation of inactivated vaccines $[6,9,66,67]$. Previously, VP1 structural proteins were successfully expressed in Arabidopsis thaliana, alfalfa, and potato plants $[66,68]$. Lower expression and detection of transgenic proteins in plants are two major limitations to the application of edible vaccines. Reporter $\beta$ glucuronidase gene was shown to facilitate rapid screening and identification of a number of transgenic plants. The selected plants developed strong and protective antibody responses against virulent FMDV in experimental hosts [9]. FMDV VP1 protein has been expressed in transgenic plants, and successful immunization in mice was also reported from China and Argentina [69,70].

Many studies have been conducted to develop FMD edible vaccines with an effective immune response in plants such as tomato, Arabidopsis thaliana, potato, Chlamydomonas chloroplasts, and tobacco [59,65,71-75]. Tissuespecific promoters increase FMD transgene expression at specific locations such as seeds for a specific time period in edible vaccines $[1,65]$. In a previous study, a novel oral immunization system was successfully developed against FMD using structural proteins (VP1) from serotypes O and Asia 1 in maize, and both transgenes were stably transmitted to the next generation [54]. Recombinant vaccines in transgenic plants such as cereals lack complications related to viral or prion adulteration in vaccines, along with many other benefits. Production of recombinant vaccines in plants is very economical and reduces transportation and storage costs [76]. Moreover, direct oral administration with multiple components makes edible vaccines more valuable [77]. Antigen expression in transgenic plants is more useful for experimental and commercial animal vaccine development as compared to classical methodologies.

\section{Conclusion}

Control and eradication of FMD from endemic regions are only possible by combined efforts of the international community to produce cost-effective and environmentally friendly vaccines against circulating FMDV serotypes. Vaccination can be an effective control measure depending on local epidemiological and scientific disease information. The effectiveness of heterologous vaccination should also be studied with respect to antigenic matching of circulating serotypes with immediate selection of effective vaccines during outbreaks. FMD vaccination strategies, vaccine production, storage, and transportation are real practical challenges, especially in developing countries. In this scenario, transgenic vaccines in plants are attractive alternatives to conventional FMD vaccines. Plants can be grown efficiently at large-scale and easily delivered. However, production of FMD chimeric plant-based vaccines from local isolates is a real challenge worldwide. Sequence analysis of circulating virus is also very important for continuous assessment of mutation and antigenic changes in the viral genome. The vaccine should be improved with circulating serotype in case of any genetic difference from the field isolate. Disease-free countries must pay special attention to protect their livestock from FMD-infected animals and animal products. Modern transgenic vaccination can be used to lower the risk of disease in FMD-free countries and can help these countries to maintain their disease-free status.

Institutional review board of Institute of Molecular Biology and Biotechnology, Bahauddin Zakariya University, approved this study.

\section{Competing interests \\ The authors declare that they have no competing interests.}

\section{Authors' contributions}

AS and SK plan and write the layout of this article and primarily edited by MAb. MAe also arranges the raw data along with MAb for article and selection of data according to layout. RSS and MA did extensive final editing of this manuscript. AS and MAb was also involved in correspondence among authors. All authors read and approved the final manuscript and agree to publish in this form.

\section{Author details}

${ }^{1}$ Instituteof Molecular Biology and Biotechnology, Bahauddin Zakariya, University, Multan, Pakistan. ${ }^{2}$ National Institute for Biotechnology and Genetic Engineering, (NIBGE), Faisalabad, Pakistan. ${ }^{3}$ National Veterinary Laboratory, Park Road, Islamabad, Pakistan. 
Received: 10 November 2014 Accepted: 16 January 2015 Published online: 01 April 2015

\section{References}

1. Mort M, Convery I, Baxter J, Bailey C. Psychosocial effects of the 2001 UK foot and mouth disease epidemic in a rural population: qualitative diary based study. BMJ. 2005;331:1234.

2. Rodriguez LL, Grubman MJ. Foot and mouth disease virus vaccines. Vaccine. 2009;4(Supplement 4):D90-4

3. Gibbs P. The foot-and-mouth disease epidemic of 2001 in the UK implications for the USA and the "war on terror". J Vet Med Educ. 2003;30:121-32.

4. Sumption K, Rweyemamu M, Wint W. Incidence and distribution of footand-mouth disease in Asia, Africa and South America; combining expert opinion, official disease information and livestock populations to assist risk assessment. Transbound Emerg Dis. 2008;55:5-13.

5. Anonymous. Foot-and-mouth disease. In: Manual of diagnostic tests and vaccines for terrestrial animals (mammals, birds and bees). Paris, France: World Organization for Animal Health (OIE); 2008.

6. Doel TR, Williams L, Barnett PV. Emergency vaccination against foot-andmouth disease: rate of development of immunity and its implications for the carrier state. Vaccine. 1994;12:592-600.

7. Abubakar M, Khan E, Arshed MJ, Hussain M, Ali Q, Afzal M. Mortality rate in association with foot and mouth disease outbreaks in cattle and buffaloes, Pakistan. ASM Sci J. 2013;7(2):139-43.

8. Rodriguez LL, Gay CG. Development of vaccines toward the global control and eradication of foot-and-mouth disease. Expert Rev Vaccines. 2011;10:377-87.

9. Dus Santos MJ, Wigdorovitz A. Transgenic plants for the production of veterinary vaccines. Immunol Cell Biol. 2005;83:229-38.

10. Seneque S Foot-and-Mouth Disease Control in Asia. Meeting Unique Challenges. in Proceedings of the Proceedings of 5th Asian Pig Veterinary Society Congress Pattaya, Thailand. 2011.

11. Correa Melo E, Saraiva V, Astudillo V. Review of the status of foot and mouth disease in countries of South America and approaches to control and eradication. Rev Sci Tech. 2002;21:429-36.

12. OIE. WAHID Interface OIE World Animal Health Information Database. 2011. http://www.wrlfmd.org/ref_labs/ref_lab_reports/OIE-FAO\%20FMD\%20Ref\% 20Lab\%20Report\%20Jan-Mar\%202011.pdf.

13. Bergmann IE, Malirat V, Falczuk AJ. Evolving perception on the benefits of vaccination as a foot and mouth disease control policy: contributions of South America. Expert Rev Vaccines. 2005:4:903-13.

14. Knowles NJ, He J, Shang Y, Wadsworth J, Valdazo-Gonzalez B, Onosato H, et al. Southeast Asian foot-and-mouth disease viruses in Eastern Asia. Emerg Infect Dis. 2012;18:499-501.

15. Jamal SM, Ahmed S, Hussain M, Ali Q. Status of foot-and-mouth disease in Pakistan. Arch Virol. 2010;155:1487-91.

16. Abubakar M, Kanwal S, Saeed A. Persistence, emergence and distribution of foot and mouth disease virus (FMDV); global and pakistan perspectives. Pak J Life Soc Sci. 2012;10(2):84-90.

17. FAO. WRLFMD Quarterly Report January-March 2011. Reference laboratory contract Reports. 2011. http://www.wrlfmd.org/ref_labs/ref_lab_reports/ OIE-FAO\%20FMD\%20Ref\%20Lab\%20Report\%20Jan-Mar\%202011.pdf.

18. Mason PW, Grubman MJ, Baxt B. Molecular basis of pathogenesis of FMDV. Virus Res. 2003;91:9-32.

19. Saeed A, Khan QM, Waheed U, Arshad M, Asif M, Farooq M. RT-PCR evaluation for identification and sequence analysis of foot-and-mouth disease serotype $\mathrm{O}$ from 2006 to 2007 in Punjab, Pakistan. Comp Immunol Microbiol Infect Dis. 2011;34:95-101.

20. Waheed U, Saeed A, Mobeen A, Khan QM. The VP1 (Capsid Protein) Gene Based DNA Sequencing for Epidemiological Analysis of FMDV, Isolated From Buffaloes in Pakistan. Pakistan J Zool (supp ser). 2009;9:333-9.

21. Abubakar M, Arshed MJ, Ali Q, Hussain M. Spatial trend of Foot and Mouth Disease virus (FMDV) serotypes in cattle and buffaloes, Pakistan. Virol Sin. 2012;27(5):320-3.

22. Bronsvoort BM, Radford AD, Tanya VN, Nfon C, Kitching RP, Morgan KL. Molecular epidemiology of foot-and-mouth disease viruses in the Adamawa province of Cameroon. J Clin Microbiol. 2004;42:2186-96.

23. Islam MA, Rahman MM, Adam KH, Marquardt O. Epidemiological implications of the molecular characterization of foot-and-mouth disease virus isolated between 1996 and 2000 in Bangladesh. Virus Genes. 2001;23:203-10.
24. Klein J, Hussain M, Ahmad M, Afzal M, Alexandersen S. Epidemiology of foot-and-mouth disease in Landhi Dairy Colony, Pakistan, the world largest Buffalo colony. Virol J. 2008;5:53.

25. Carrillo C, Tulman ER, Delhon G, Lu Z, Carreno A, Vagnozzi A, et al. Comparative genomics of foot-and-mouth disease virus. J Virol. 2005;79:6487-504.

26. Jackson AL, O'Neill H, Maree F, Blignaut B, Carrillo C, Rodriguez L, et al. Mosaic structure of foot-and-mouth disease virus genomes. J Gen Virol. 2007;88:487-92.

27. Aidaros HA. Regional status and approaches to control and eradication of foot and mouth disease in the Middle East and North Africa. Rev Sci Tech. 2002;21:451-8. http://dx.doi.org/10.14737/journal.rjvp/2014/2.2.28.29.

28. Bastos AD, Haydon DT, Sangare O, Boshoff Cl, Edrich JL, Thomson GR. The implications of virus diversity within the SAT 2 serotype for control of foot-and-mouth disease in sub-Saharan Africa. J Gen Virol. 2003;84:1595-606.

29. OIE. WAHID Interface OIE World Animal Health Information Database. 2008 https://www.oie.int/wahis/content.php?page=home\&sslcheck=true.

30. Kitching RP. Global epidemiology and prospects for control of foot-andmouth disease. Curr Top Microbiol Immunol. 2005;288:133-48.

31. Taboga O, Tami C, Carrillo E, Nunez Jl, Rodriguez A, Saiz JC, et al. A large-scale evaluation of peptide vaccines against foot-and-mouth disease: lack of solid protection in cattle and isolation of escape mutants. J Virol. 1997;71:2606-14.

32. Fry EE, Lea SM, Jackson T, Newman JW, Ellard FM, Blakemore WE, et al. The structure and function of a foot-and-mouth disease virus-oligosaccharide receptor complex. EMBO J. 1999;18:543-54.

33. Alexandersen S, Zhang Z, Donaldson Al. Aspects of the persistence of footand-mouth disease virus in animals-the carrier problem. Microbes Infect. 2002:4:1099-110

34. Doel TR. FMD vaccines. Virus Res. 2003;91:81-99.

35. Pan $L$, Zhang $Y$, Wang $Y$, Wang $B$, Wang $W$, Fang $Y$, et al. Foliar extracts from transgenic tomato plants expressing the structural polyprotein, p 1-2A, and protease, 3C, from foot-and-mouth disease virus elicit a protective response in guinea pigs. Vet Immunol Immunopathol. 2008;121:83-90.

36. Sobrino F, Saiz M, Jimenez-Clavero MA, Nunez Jl, Rosas MF, Baranowski E, et al. Foot-and-mouth disease virus: a long known virus, but a current threat. Vet Res. 2001;32:1-30.

37. McKenna TS, Lubroth J, Rieder E, Baxt B, Mason PW. Receptor binding sitedeleted foot-and-mouth disease (FMD) virus protects cattle from FMD. J Virol. 1995;69:5787-90.

38. Selim A, Abouzeid N, Agaour A, Sobhy N. Comparative study for immune efficacy of two different adjuvants bivalent FMD vaccines in sheep. J Am Sci. 2010;6:1292-8.

39. Deghaidy W, Daoud A, El-Molla A. Immune response of sheep to foot and mouth disease vaccines containing different adjuvants. Small Rumin Res. 2002:45:185-92.

40. Hunter P. Vaccination as a means of control of foot-and-mouth disease in sub-saharan Africa. Vaccine. 1998;16:261-4.

41. Iyer AV, Ghosh S, Singh SN, Deshmukh RA. Evaluation of three 'ready to formulate' oil adjuvants for foot-and-mouth disease vaccine production. Vaccine. 2000;19:1097-105.

42. Lombard M, Pastoret PP, Moulin AM. A brief history of vaccines and vaccination. Rev Sci Tech. 2007;26:29-48.

43. Abubakar M, Jamil A, Ali Q. An evaluation of foot-and-mouth disease outbreak in relation to vaccination in a herd of cattle and buffaloes. Res J Vet Pract. 2014;2(2):28-9.

44. Batista A, Quattrocchi V, Olivera V, Langellotti C, Pappalardo JS, Di Giacomo S, et al. Adjuvant effect of Cliptox on the protective immune response induced by an inactivated vaccine against foot and mouth disease virus in mice. Vaccine. 2010;28:6361-6.

45. Rieder E, Baxt B, Lubroth J, Mason PW. Vaccines prepared from chimeras of foot-and-mouth disease virus (FMDV) induce neutralizing antibodies and protective immunity to multiple serotypes of FMDV. J Virol. 1994;68:7092-8.

46. Mason PW, Piccone ME, McKenna TS, Chinsangaram J, Grubman MJ. Evaluation of a live-attenuated foot-and-mouth disease virus as a vaccine candidate. Virology. 1997;227:96-102.

47. Pfaff E, Mussgay M, Bohm HO, Schulz GE, Schaller H. Antibodies against a preselected peptide recognize and neutralize foot and mouth disease virus. EMBO J. 1982; 1:869-74

48. Li Z, Yin X, Yi Y, Li X, Li B, Lan X, et al. FMD subunit vaccine produced using a silkworm-baculovirus expression system: protective efficacy against two type Asia1 isolates in cattle. Vet Microbiol. 2011;149:99-103. 
49. Bittle JL, Houghten RA, Alexander H, Shinnick TM, Sutcliffe JG, Lerner RA, et al. Protection against foot-and-mouth disease by immunization with a chemically synthesized peptide predicted from the viral nucleotide sequence. Nature. 1982;298:30-3.

50. Collen T, Dimarchi R, Doel TR. A T cell epitope in VP1 of foot-and-mouth disease virus is immunodominant for vaccinated cattle. J Immunol. 1991;146:749-55

51. Domingo E, Mateu MG, Matnez MA, Dopazo J, Moya A, Sobrino F. Genetic variability and antigenic diversity of foot-and-mouth disease virus. Appl Virol Res. 1990;2:233-66.

52. Frimann TH, Barfoed AM, Aasted B, Kamstrup S. Vaccination of mice with plasmids expressing processed capsid protein of foot-and-mouth disease virus-importance of dominant and subdominant epitopes for antigenicity and protection. Vaccine. 2007;25:6191-200.

53. Cubillos C, de la Torre BG, Jakab A, Clementi G, Borras E, Barcena J, et al. Enhanced mucosal immunoglobulin $A$ response and solid protection against foot-and-mouth disease virus challenge induced by a novel dendrimeric peptide. J Virol. 2008;82:7223-30.

54. Zhang L, Zhang J, Chen HT, Zhou JH, Ma LN, Ding YZ, et al. Research in advance for FMD novel vaccines. Virol J. 2011;8:268.

55. Bae JY, Moon SH, Choi JA, Park JS, Hahn BS, Kim KY, et al. Recombinant DNA and protein vaccines for foot-and-mouth disease induce humoral and cellular immune responses in mice. Immune Netw. 2009;9:265-73.

56. McCullough KC, De Simone F, Brocchi E, Capucci L, Crowther JR, Kihm U. Protective immune response against foot-and-mouth disease. J Virol. 1992;66:1835-40

57. Nain V, Verma A, Kumar N, Sharma P, Ramesh B, Kumar PA. Cloning of an ovule specific promoter from Arabidopsis thaliana and expression of beta-glucuronidase. Indian J Exp Biol. 2008;46:207-11.

58. Saiz JC, Cairo J, Medina M, Zuidema D, Abrams C, Belsham GJ, et al. Unprocessed foot-and-mouth disease virus capsid precursor displays discontinuous epitopes involved in viral neutralization. J Virol. 1994;68:4557-64.

59. Andrianova EP, Krementsugskaia SR, Lugovskaia NN, Mayorova TK, Borisov W, Eldarov MA, et al. Foot and mouth disease virus polyepitope protein produced in bacteria and plants induces protective immunity in guinea pigs. Biochemistry (Mosc). 2011;76:339-46.

60. Grubman MJ, Baxt B. Foot-and-mouth disease. Clin Microbiol Rev. 2004;17:465-93.

61. Grubman MJ. Development of novel strategies to control foot-and-mouth disease: marker vaccines and antivirals. Biologicals. 2005;33:227-34.

62. Grubman MJ, Moraes MP, Schutta C, Barrera J, Neilan J, Ettyreddy D, et al. Adenovirus serotype 5-vectored foot-and-mouth disease subunit vaccines: the first decade. Futur Virol. 2009;5:51-64.

63. Pacheco JM, Brum MC, Moraes MP, Golde WT, Grubman MJ. Rapid protection of cattle from direct challenge with foot-and-mouth disease virus (FMDV) by a single inoculation with an adenovirus-vectored FMDV subunit vaccine. Virology. 2005;337:205-9.

64. Li $X$, Liu $R$, Tang $H$, Jin M, Chen $H$, Qian P. Induction of protective immunity in swine by immunization with live attenuated recombinant pseudorabies virus expressing the capsid precursor encoding regions of foot-and-mouth disease virus. Vaccine. 2008;26:2714-22.

65. Mason HS, Ball JM, Shi JJ, Jiang X, Estes MK, Arntzen CJ. Expression of Norwalk virus capsid protein in transgenic tobacco and potato and its oral immunogenicity in mice. Proc Natl Acad Sci U S A. 1996;93:5335-40.

66. Wigdorovitz A, Mozgovoj M, Santos MJ, Parreno V, Gomez C, Perez-Filgueira $\mathrm{DM}$, et al. Protective lactogenic immunity conferred by an edible peptide vaccine to bovine rotavirus produced in transgenic plants. J Gen Virol. 2004;85:1825-32.

67. Zulfiqar M. Support for Emergency Prevention and Control of Main Trans-boundary Animal Diseases in Pakistan, Rinderpest, FMD, PPR. 2003.

68. Carrillo C, Wigdorovitz A, Oliveros JC, Zamorano PI, Sadir AM, Gomez N, et al. Protective immune response to foot-and-mouth disease virus with VP1 expressed in transgenic plants. J Virol. 1998;72:1688-90.

69. Wigdorovitz A, Carrillo C, Dus Santos MJ, Trono K, Peralta A, Gomez MC, et al. Induction of a protective antibody response to foot and mouth disease virus in mice following oral or parenteral immunization with alfalfa transgenic plants expressing the viral structural protein VP1. Virology. 1999;255:347-53.

70. Carrillo C, Wigdorovitz A, Trono K, Dus Santos MJ, Castanon S, Sadir AM, et al. Induction of a virus-specific antibody response to foot and mouth disease virus using the structural protein VP1 expressed in transgenic potato plants. Viral Immunol. 2001;14:49-57.

71. Haq TA, Mason HS, Clements JD, Arntzen CJ. Oral immunization with a recombinant bacterial antigen produced in transgenic plant. Science. 1995;268:714-6.

72. Thanavala Y, Yang YF, Lyons P, Mason HS, Arntzen C. Immunogenicity of transgenic plant-derived hepatitis B surface antigen. Proc Natl Acad Sci U S A. 1995;92:3358-61.

73. Sun M, Qian K, Su N, Chang H, Liu J, Shen G. Foot-and-mouth disease virus VP1 protein fused with cholera toxin B subunit expressed in Chlamydomonas reinhardtii chloroplast. Biotechnol Lett. 2003;25:1087-92.

74. He DM, Qian KX, Shen GF, Li YN, Zhang ZF, Su ZL, et al. Stable expression of foot-and-mouth disease virus protein VP1 fused with cholera toxin B subunit in the potato (Solanum tuberosum). Colloids Surf B Biointerfaces. 2007:55:159-63.

75. Joensuu JJ, Brown KD, Conley AJ, Clavijo A, Menassa R, Brandle JE. Expression and purification of an anti-Foot-and-mouth disease virus single chain variable antibody fragment in tobacco plants. Transgenic Res. 2009;18:685-96.

76. Hood E, Witcher D, Maddock S, Meyer T, Baszczynski C, Bailey M, et al. Commercial production of avidin from transgenic maize: characterization of transformant, production, processing, extraction and purification. Mol Breed. 1997;3:291-306

77. Streatfield SJ, Jilka JM, Hood EE, Turner DD, Bailey MR, Mayor JM, et al. Plant-based vaccines: unique advantages. Vaccine. 2001;19:2742-8.

\section{Submit your next manuscript to BioMed Central and take full advantage of:}

- Convenient online submission

- Thorough peer review

- No space constraints or color figure charges

- Immediate publication on acceptance

- Inclusion in PubMed, CAS, Scopus and Google Scholar

- Research which is freely available for redistribution 